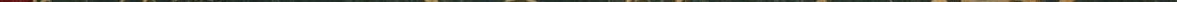




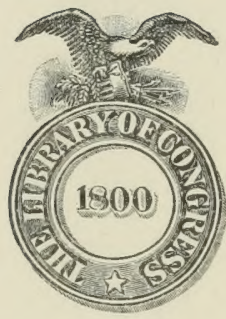

Class SB405

Book $1 / 13$

Copyright N.

COPYRIGHT DEPOSIT: 


\section{How to Plant the \\ Home Grounds}

PRICE, 10 CENTS

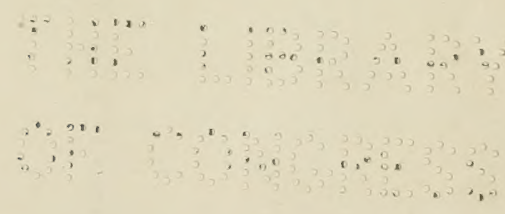

Beautiful America Leaflet No. 2 Issued by The Ladies' Home Journal 


\section{SB405 \\ - Mis}

\begin{tabular}{|} 
LIBRARY of CONGRESS \\
Two Coples Received \\
MAR 251904 \\
Copyright Entry \\
Mau. 25 - 19 0 4 \\
CLASS a XXc. No \\
82695 \\
COPY 3
\end{tabular}

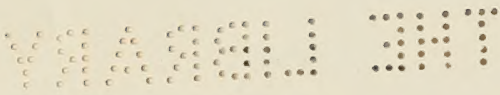

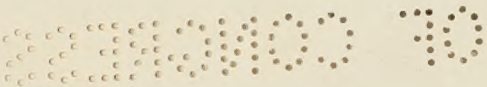




\section{How to Plant the Home Grounds}

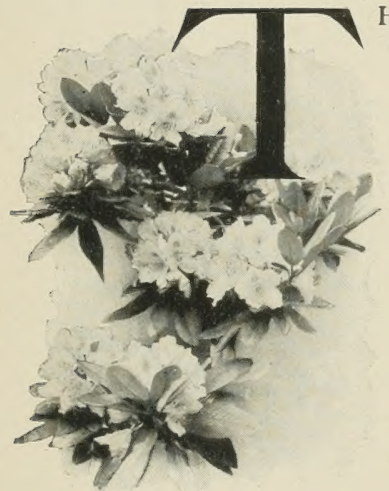

mediate home grounds elsewhere; but not to lay down laws for the improvement of large areas, where the contour and situation call for special treatment by the landscape architect.

The saving touch of greenery at least, and the refreshment of flowers usually, can be had anywhere in America, from Florida to British Columbia, regardless of sun, cold, soil or exposure. Something will grow everywhere to beautify the home grounds. Only knowledge and discrimination as to what to plant, and a little care as to how, are required, with a reasonable interest to maintain proper growing conditions afterward.

1. A Plan Desirable. Begin right, by making a plan to a definite scale of your home grounds, however small. This may be a mere outline sketch, allowing say a half-inch or an inch to each foot of the actual dimensions. Locate everything - the house, the fence, the out-buildings, the entrances. This plan will show the home grounds as you would see them looking down from a balloon suspended fifty

Copyright, 1004, by The Curtis Publishing Company 


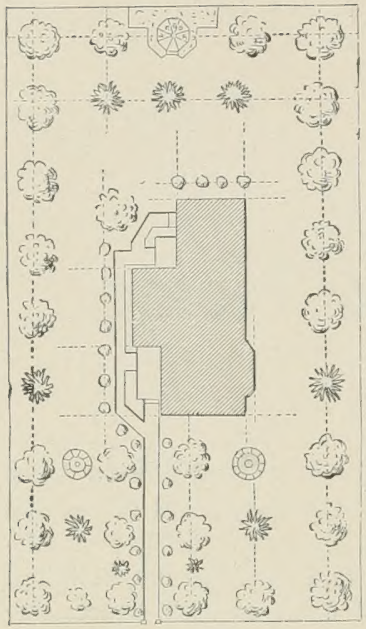

Fig. 1. Showing the effect of having lawn trees, shrubs, walks, etc., arranged in straight lines.

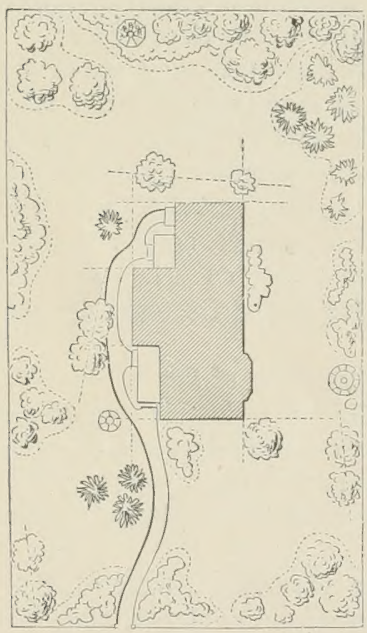

Fig. 2. Showing the advantage of placing the features of the lawn in irregular order and employing curves. Note the open spaces. or a hundred feet directly above. After it is filled in, your plan will probably look something like Figures 1 or 2.

2. Consider the Planting. On the plan, there will have been located any existing trees, plants or vines, and the work to a considerable extent will center around these. Are they now located where they are doing most for the home? Be careful about removing entircly any established growths; it is easier to cut down than to replace. Sometimes a tree or plant may need to be moved to another situation; sometimes it is hopelessly wrong for the place and must be altogether taken out. One efficient, well-placed tree or shrub is worth a dozen that are crowded, sickly or illplaced.

3. Simplicity Desirable. Often the unguided feeling for improvement leads to a mixed-up or complex design, and to indiscriminate, crowded planting. By all means, have the home grounds planned for simplicity. I remember a dooryard in which the home-owner had been persuaded by a tree agent to set out a dozen Kilmarnock willows, spaced at regular distances, and making, as they grew, a grotesque and absurd travesty of a proper home arrangement. One little corner arrangement of a clematis and some hardy plants is far better, as in Figure 3 ; and much lawn with few shrubs is by far preferable to an expensively crowded home area.

4. Do Not Imitate Without Reason. To see a home lot well planted somewhere nay excite a desire-and a proper one-for equally beautiful planting; but it is not necessary to imitate. Frequently the admired place is in a totally different situation, using perhaps plants that are not best for your home grounds. By all means, choose such plants and trees as are acclimated and adapted to your own home.

5. Open Spaces of Grass. Nothing so adds to the restful character of the home grounds as an open space of turf, be it ever so small. Even the space of two yards square (but not laid out 
square, by any means!) in clean grass will be far superior in effect to the same space jammed with plants. I have a friend who has.his twenty-foot dooryard so disposed as to make it look park-like, and far larger than it really is. He does it (a) by maintaining a little bit of lawn, and (b) by planting the profusion of flowers he always has in simple borders. Figures $I$ and 2 show how the same space may be crowded or open, according to its poor or proper arrangement, and the open areas for grass are seen to appear at once in Figure 2.

6. Avoid Straight Lines. Nature has little use in her work for "the shortest distance between two points." Our homegrounds are us ually bounded by a rectangle, and that affords straightness enough. Judicious curves help greatly in making beautiful homegrounds, and they afford natural places for groups of plants or small trees, as well. Refer again to Figures $I$ and 2 for evidence as to curves. Plants themselves avoid the straight-edge, and will, if left alone, soon open out into grace, and get away from the unnecessary and unnatural direct line. But curves without reason are mere wiggles, and thus worse than the severely straight disposition. Figures 4

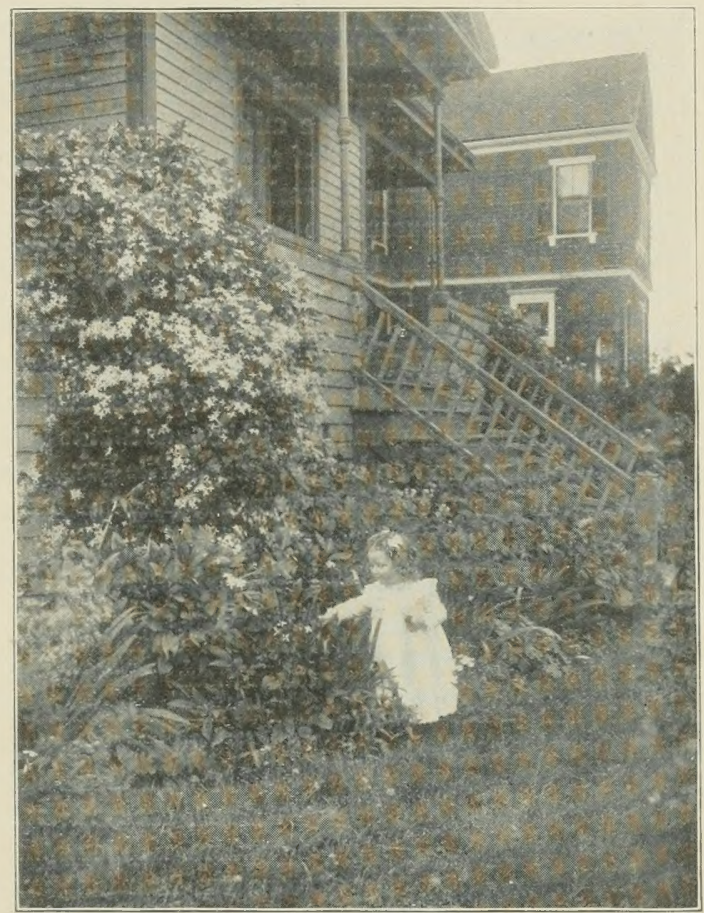

Fig. 3. A lirtle corner arrangement of Clematis paniculata and some hardy plants

and 5 contrast the bad and the better arrangement, and the walk from the front in Figure 2 also shows a desirable curve.

7. Slopes, Rather than Terraces. If your home-yard rises sharply from the highway, a proper access must be had. A terrace is a step cut in the ground. Necessary occasionally for a considerable ascent, it is always difficult to keep in order. Nature slop ss all her banks; let us use slopes if possible. Sometimes careful grad- 
ing will bring the last steep slope or rise next the house, and there we may use steps to the entrance, securing in the rest of the slope a great chance for effective planting

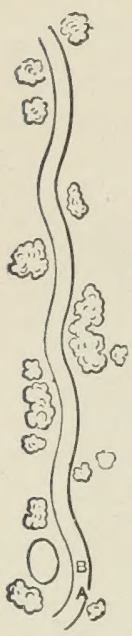

Fig. 4.

A series of characterless serpentin e curves. of vines - honeysuckle will cover any bank; multiflora, Wichuraiana or rugosa roses; matrimony vine, wistaria, trumpet vine, dutchman's pipe, and a dozen others, all hardy and permanent, will make a steep slope a thing of beauty.

8. Plan and Plant Appropriately. To be attracted by a stately elm in perfection after a generation's growth in a park, and therefore to plant an elm in a little dooryard, is a mistake not infrequently made. To make the best of the space at command, we must plant to suit it, considering (a) the space we have, (b) the exposure to the sun, (c) the character of the soil, and (d) the ultimate size of the tree or plant of which we are enamored. Figure 6 shows how an unwholesome crowding resulted from lack of consideration of the last item. Again, if it is a tree you are planting, consider carefully its mature shape-whether it makes a rounded head, or one that is pyramidal, or resembling an inverted cone. The grand elms of New England are of the latter shape, while a sugar maple takes up more room below. See Figures 7 and 8 for examples, and note that shrubs also have a definite shape, not always amenable to training. Figure 9

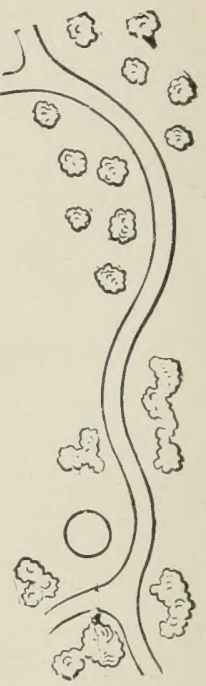

Fig. 5.

Pleasing curves, because the bends vary considerably in size.

shows a Deutzia gracilis that was not calculated for, with the result that the teams coming to the house continually bother it. Figure ro shows an adequate provision for the Hydrangea paniculata grandiflora (it is strange that this universal shrub has not been common-named!) along the walk.

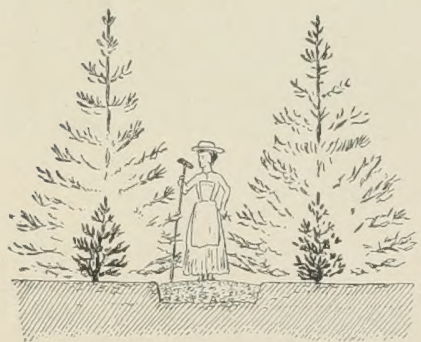

Fig. 6. The small evergreens seemed far enough from the waik when they were planted, but six years of growth showed the mistake.
9. The Small Dooryard. As previously insisted, the smallest space can be planted, anywhere. About the door, vines can be grown; a ten-inch hole is all that is needed for the superb Boston ivy (Ampelopsis Veitchii), and little more will be required for the Japan honeysuckle. Both will gradually work above the shade and revel in the sun. With a little more sun, a Crimson Rambler rose will thrive. If hopelessly shady, and with but little space, have use of the hardy ferns; they will get along without any sun at all, and lily-of-the-valley (bulbous, planted in autumn) will bloom among the ferns, before the 


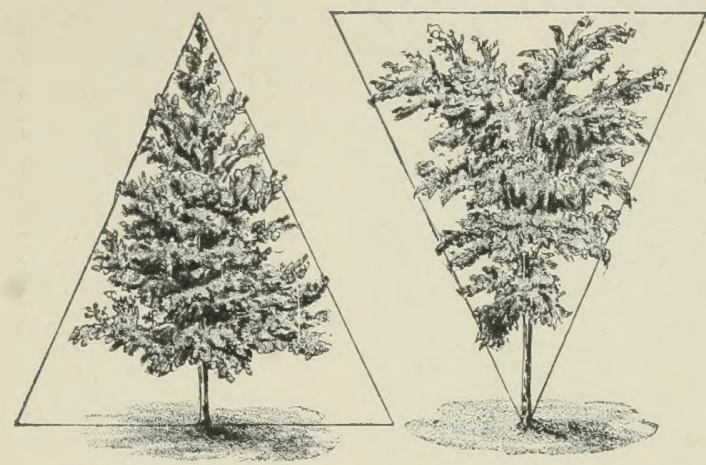

Fig. 7. The heaviest growth in the bottom branches; hence not well suited for street planting, where long trunks are desirable.
Fig. 8. The heaviest growth at the top, inducing the tree to have a high trunk; hence well suited for street planting.

fronds unfold. Figure ir shows how ferns will brighten a little strip at the porch edge, and these stood the rain drip, too. Pansies will bloom in partial shade; so will St. John's-wort, and our superb mountain laurel will enliven a spot that is nearly sunless. Of course the hardy bulbs will bloom in shady placesthe hyacinths, the tulips and narcissi, the crocuses and snowdrops. These, too, can be planted under tree shade, for their bloom is nearly over before the leaves come.

But our dooryard or back yard may be sunny, and not shaded. The vines will grow, and more of them-trumpet vine, wistaria, the clematises, the annual hyacinth bean, and very many others. The fine blue spirea, which is not a spirea at all, will fairly glow in the sunshine; the hardy phlox will give richest coloring and a splendid showing all the late summer. The deutzias, spireas, weigelas and hydrangeas will do superbly, and the golden wands of the forsythia will open in earliest spring.

Is it sandy in the yard, as along the seacoast? Sunflowers and hypericums will grow; the vincas or periwinkles will fairly cover themselves with bloom; the lovely little portulacas will defy both sand and

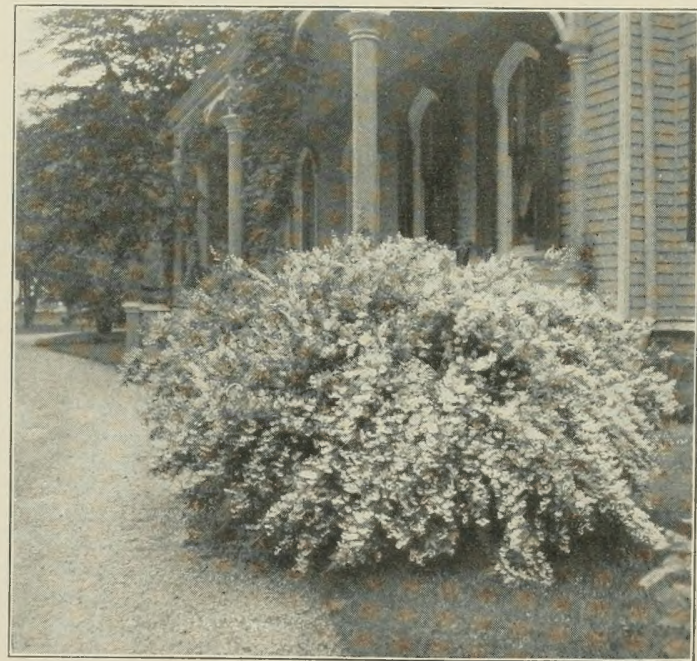

Fig. 9. Deutzia gracilis planted too near the drive $[7]$ 


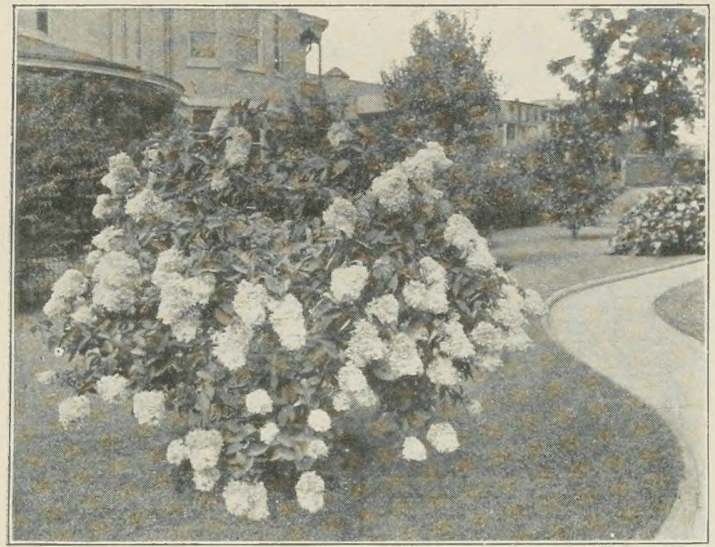

Fig. 10. Hydrangea paniculata grandiflora planted in its proper place well back from the walk sun; blazing star and cobea will bloom. For rocks, there are scores of plants; campanulas, the exquisite moss-pink, the sweet daphne, the hardy cactuses. For heavy clay many hardy plants are available; the lilac, the altheas, the columbine, the gas plant, the lovely forgetme-not. There are annuals of merit also for clay, including sweet peas and zinnias.

10. A Naturai Plan for the Larger Areas.

All that has been said of the dooryard applies to the larger grounds, and more, for here may be planted the shrubs of more robust growth, as well as smaller trees. I can suggest no better way to improve and plan a suburban lot, a small country home, the farmhouse flower-garden, than to propose careful consideration of the plants and trees native to the neighborhood. In a certain city a well-planted yard on a prominent street shows for three midsummer weeks a superb rose-mallow in bloom, always attracting attention; yet, within two miles of the spot, five acres of the same plant bloom almost unseen, and tens of thousands of "commuters" see-or don't see!-hundreds of acres softly aglow with the same rose-mallow as they cross the Hackensack marshes daily! How much better to individualize these plants of the neighborhood, sure to do well, than to work only with the monotony of geranium, coleus, canna and verbena! A few trips to the woods and meadows nearest the home-and I have purposely spoken of beautiful but common flowers seen near to the greatest congestion of urban population in the United States, having also seen many lovely wild things in bloom close to the smoke of Chicago-will give suggestions worth while.

11. Plant for Succession of Bloom and Interest. The proper home-garden should show something interesting every day from snow to snow, from crocus to chrysanthemum. Often there is a fine burst of spring bloom followed by a lack of flowers in the summer months. This need not be, for, with care in selection, something attractive can be had all the growing season. Even with purely hardy plants this may be arranged, and it is quite easy if some of the good annuals are also included. A few suggestions follow; they should be considered in connection with the remarks as to location and conditions found in section 9 . 
12. For Spring Bloom. 'This list is made purposely sparse, as in every locality the spring provides a profusion of Howers.

Bulbs, planted the autumn before; hardy, and may be left in the ground; other plants may follow them as foliage dies away: Snowdrops, crocus, squills, early and late tulips, hyacinths of many kinds (may frecze if unprotected in the far North), daffodils, and other narcissi; and for shady places trilliums, dog'stooth violets, lily-of-the-valley.

Hardy Low-grozuing Plants, set the autumn before if possible: Moss-pink, columbines, sweet-williams, clove pinks, dwarf and German iris; and for shade, blue phlox, spring beauty, bluets, Virginia corslip, toothwort, moccasin flowers, dutchman's breeches, hepatica, bloodroot; many ferns; English daisy, hardy primroses, periwinkle.

Shrubs and Larger Plants: Forsythia, Deutzia gracilis, early spireas, peonies, bleeding-heart, Oriental poppies, lychnis, Japanese and Siberian iris, many lilacs, spice-bush, mock orange, many roses, snowballs and other viburnums, dogwoods, weigelas, bush honeysuckles, elders, the smaller magnolias; also, good but less hardy, tamarix, Japan quince, jasminum, Azalea mollis and amcena.

Trees, especially small trees suited for lazuns: Double-flowering apples, wild crab, Chinese crab, Siberian crab, magnolias, white dogwood, havthorns, yellow-wood, red-bud, Japan tree lilac, koelreuteria.

13. For Midsummer and Early Fall. This is the time when bloom is likely to be scarce, and the planting ought to be carefully worked out

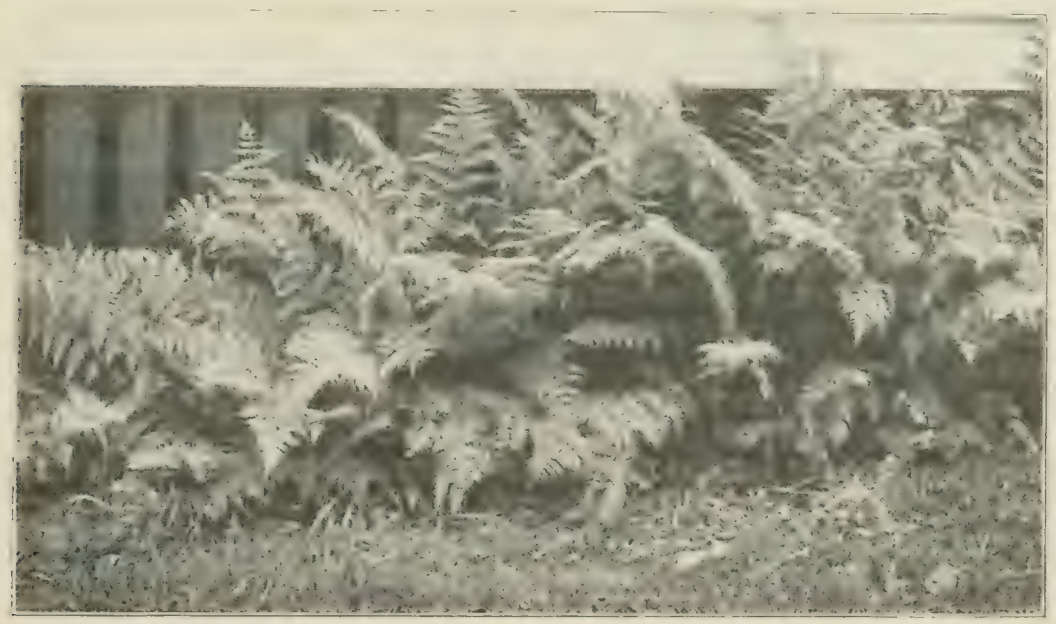

Fig 11. Hardy ferns growing luxuriantly in front of the porch in the shade 
Bulbs, not hardy over winter, planted early and in several successive plantings (except the hardy lilies, which should go into the ground the autumn previous): Gladioli, tigridias and tuberoses; many fine hardy lilies. Dahlias are superb till frost (tuberous roots, planted in spring).

Hardy Herbs, Shrubs and Plants, planted early in same season: Hollyhocks, perennial sunflowers, Golden Glow and other rudbeckias, monardas, cardinal Hower (in wet places), American rhododendrons (in shady places, not in limestone soil), late spireas, achilleas, tansy, perennial phlox, caryopteris, hemerocallis, funkias, later canterbury bells and larkspurs, fire-pink, Japan anemones, rose-mallow, water-lilies and lotuses (for the aquatic garden), boneset, Joe-pye, black cohosh, dwarf horse-chestnut, coreopsis, aconite, purple loosestrife, sumacs, white elder.

Annuals, grown from seed the same season: Alyssum, candytuft, summer chrysanthemums, coreopsis, marigolds, coxcombs, portulacas, annual sunfowers, ten-weeks stocks, four-o'clocks, verbenas, clarkia, zinnias, garden asters, Shirley poppies, Drummond phlox, dwarf nasturtium, dianthus (perennials and biennials).

Large Trees that bloon or are otherwise especially attractive: Sweet chestnut, tulip or liriodendron, bassivood, locust, catalpas, maples, liquidambar.

14. For Late Fall, until Cut off by Frost, and for Winter. Including some fine plants, to round out the season; there are many others.

Plants: Various hydrangeas, various goldenrods, many fine hardy asters, boltonias, hardy chrysanthemums (some of the Japanese varieties become hardy).

Plants and Trees Attractive in Fall by reason of showy fruits are exceedingly useful, and have not been availed of to any great extent; most of them furnish also handsome bloom earlier in the season: All the dogwoods, including kinds with red, black and blue berries and red bark; snowberry and Indian currant; all the viburnums (these are superb both in flower and fruit, and some have foliage that colors brilliantly); both American and European mountain ashes; witch-hazel blooms about freezing time; foliage and fruit of Thunberg's and the common barberry, black alder, red-berried alder.

Plants and Trees Beautiful in Winter. All the evergreens, especially spruces, pines, firs and cedars, and some of the retinosporas (not hardy in the North); Japanese and American hollies (not hardy Norsh); the various box trees, rhododendrons and laurel in other than limestone soil; euonymus, Mahonias, trees with bright bark.

15. These Lists Are Incomplete. They are intended to start home improvers in various parts of America to noting for themselves the trees, shrubs, vines and plants that are doing best and covering the longest seasons of usefulness in their own neighborhoods. If this inquiry is made, it will undoubtedly result in much successful home-ground planting out of the ordinary, and both permanent and pleasing. It should be remembered that many herbs and shrubs can be easily transplanted from near-by woods and fields, and these are often fully as attractive as the garden kinds. Some nurserymen make a specialty of the "wild" plants. 
16. Tropical and Tender Plants. It has been well said that only the very rich can afford to adorn the home-grounds with palms and the like; yet one sees most frequently the plants of ephemeral character-cannas, coleus, geraniums, palms, tender ferns, etc. Scarcely a score of species are included in the usual round of easily grown and as easily killed plants offered for home adornment by the florists; yet I have named at least a hundred hardy plants and vines that give greater beauty from time to time, and increase in strength from year to year. True, these hardy plants do not bloom continually, but that is one of their merits; for it means a changing feast of flowers in the well-planted home-yard, and $\mathrm{th}$ is without the elaborate and continual attention required to keep in order the ordinary "beds" that are the same from July until frost. An occasional palm or fern as a pet plant, to be taken into the living-room over winter; some of the easy-blooming tender plants for the window box; heliotropes and mignonette and siveet alyssum for fragrance

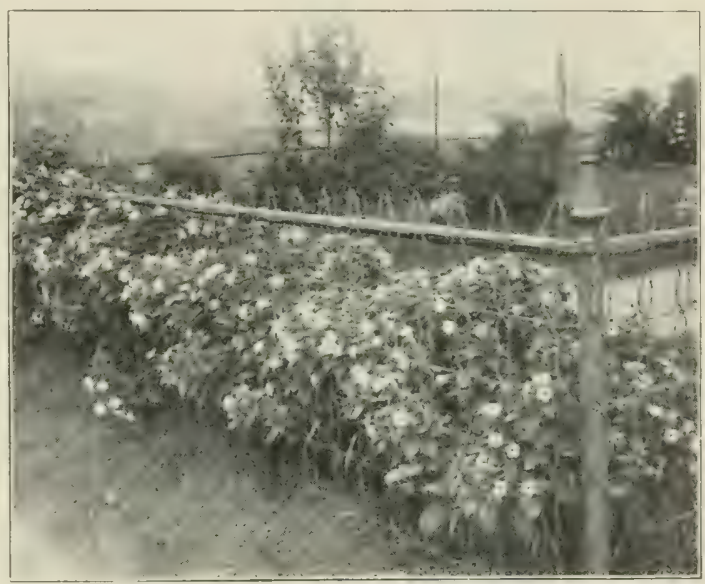

Fig. 12. Marvel-of-Peru, or Four-o'clock, makes a beautiful fence cover in the home-these can be cared for to advantage. The main reliance, however, should be on hardy plants and vines, needing no recurring annual expense.

17. Annual Flowers. By these I mean the pansies, balsams, salvias, marigolds, four-o'clocks, garden asters, zinnias, cockscombs, and scores of other beautiful flowers that give bloom the same season the seed is sown. They fill in the gaps while the hardy plants are growing, and have merits of their own. A half dollar's worth of seed will do wonders. See the fence-covering of marvel-of-peru in Figure 12, giving bloom for nearly three months, right up to frost, and costing just one dime! There are quick-growing annuals that are fine to serve as screens for unsightly spots that cannot be removed. Sunflowers, castor beans, cosmos ivill soon shade the ash-barrel.

18. Plant Vines, Both Hardy and Tender. Perhaps the gospel of vines for the home grounds has not been preached with enough vigor in these hints. The vines add to all the graces of the standard shrub or plant the final one of ability to creep 
or climb. They are beautiful and interesting in growth as well as in bloom. Some will creep or climb unaided; others require support. Suggestions follow, as to adaptability.

Vines for the city lome, on wall or porch, are Rambler roses, Wichuraiana, Dawson and multiflora roses (see Figure ${ }_{3} 3$ for a two-year rose effort), Boston ivy, English ivy, Virginia creeper, Clematis paniculata (superb); Clematis flammula, Virginiana, coccinea and crispa, honeysuckles of several sorts, matrimony vine, Akebia quinata; all these are hardy and will do in small area. For lustier grosth, other hardy vines are Chinese wistaria, trumpet creeper, actinidia (a grand thing), dutchman's pipe, bitter-sweet. Annuals growing from the seed are morningglories, Scarlet Runner bean, balloon vine, Japanese hop, and many others, not forgetting the indispensable sweet pea, which should be planted early.

Trailers, to cover a bank, include the Wichuraiana and multiflora roses, the Japan honeysuckles, Clematis Virginiana, periwinkle, bitter-siveet; and for shady places, otherwise bare, use Creeping Charlie, partridge vine, galax; even violets will grow.

19. Have Growing Fences or Hedges, or Cover the Fence with Vines. The very best way to take away the hatefulness of a fence is to cover it with something beautiful, good for the fencer and the fenced to see. See Figure 12 for a cheap and bright fence alleviator. For a hardy hedge, that is a fence in itself, plant California privet, Amoor River privet, Japanese quince, several barberries, Ro:a rugosa, cockspur thorn, altheas. Any of the evergreen honeysuckles wil! make a fine hedge, and the deutzias and spireas are excellent, as are most of the viburnums. Any of the climbing annuals will cover a fence, and I am partial to the vine of the sweet potato, also. Do not plant evergreen hedges of pine and spruce, for they grow too high, and are hard to restrain without great expense for trimming, also spreading too much horizontally. (See Figure 6.)

20. As to Preparation of Soil. Having discussed plans and plants, we may well turn to the ground in which they are to be made effective. Formerly there was a great prolixity of directions for the mixing of soils for various plants, and the English gardening books give many prescriptions that would be hard to fill. Plants have a habit of growing under all sorts of soil conditions; I have seen the periwinkle doing well in heavy soil, and have seen it fairly riot in the Florida white sand. To get home results, let us do the best we can; and that means at least the thorough stirring of the soil, deep enough to give the plant roots a chance. If you make it easy for them to penetrate the ground for food and moisture, they will give you evidences of that fact in bloom and in growth.

There are only a few truisms about soils. Very heavy clayey soils need to be broken up and made lighter. Coal ashes will do it and sand will do it; a shovel and rake must intervene. Turning in deeply loose manure or rotted sods will help doubly; planting the various clovers-red and scarlet-will both break up the soil and add "humus" if the clovers are then turned in, after growing to the height of 
a foot or less. These heavy soils are happiness for some plants; simply tame the ground to your needs. In sand, it is difficult to add the lacking element of clay and easier to adapt the planting to the sand. But always the ground can be fully dug and pulverized, and that is much. Some rotted sods or manure will add fertility.

21. Plants Do not Like Wet Feet. Except for the purely aquatic and bog plants, water standing about the roots is fatal. That is one reason for thorough and deep digging, and for the addition of lighter material to clay soils-to afford an opportunity for the surplus water to pass through. If the home grounds are damp, dig deeply and see that there is enough depth and opening to drain the ground of superfluous moisture.

22. Give the Plants a Start with Good Soil. Figures It and Is illustrate this point, both as to locating a tree or shrub, and as to a vine against the house. To put old sods, and old bones as well, at the bottom of these holes, is to provide a store of fertility in connection with the good loam that it is best to use around the trees or plants.

23. Planting Hints. Do not set the plants deeper than they were in the nursery. Plant solidly, firming the ground by tramping with the feet, or by the use of a maul. This may seem a contradiction, but it isn't : we dig and pulverize the soil to break it up into small particles; we firm it around the plant to keep air away and to bring these particles in contact with the roots. Cover the ground after planting with some loose material, as leaves, sawdust, bagging, sand, to keep the sun's rays from too soon and too strongly acting upon the roots.

24. Nearly All Plants and Trees Need Trimming When Planted. This is to restore the balance between root and top. See Figure 16 to know why, and also to know that a larger proportion of necessary roots is obtained with small, thrifty trees than with larger ones. Trim carefully, cutting out crossing and opposing twigs; cut close to a bud; use a sharp knife. Trim any torn ends of roots, also; root growth frequently starts from these trimmed ends. Do not allow the roots to become dry while you are preparing the ground or planting; they are just as unhappy in the air as a fish. Keep

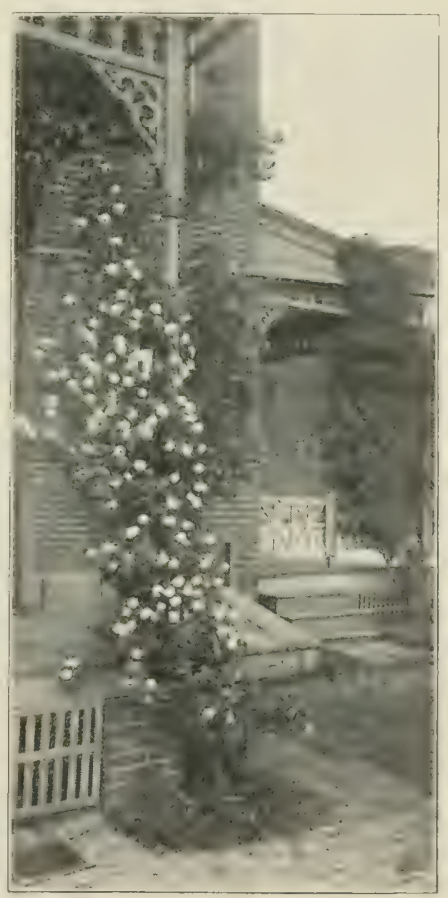

Fig. 13. A two-year-old climbing rose 
the roots in moist ground, or in a puddle of mud, until the moment of planting. Plants whose roots have never dried out grow sooner and faster than those that have been hurt by the air and the sun acting on the parts nature wants covered.

25. About Watering. On the whole, it is best not to water plants, if they have been carefully set in good soil, soaked after planting, and provided with a "mulch" to keep off the sun's rays for a while. Daily sprinkling of the ground is a positive detriment; a weekly soaking, thoroughly done, is useful in a very dry time. The best way to provide water is to keep in the soil what is there for the plant's use by constant and thorough cultivation. I know a skilful grower of dahlias who yearly sets out over fifty acres of those beautiful but water-

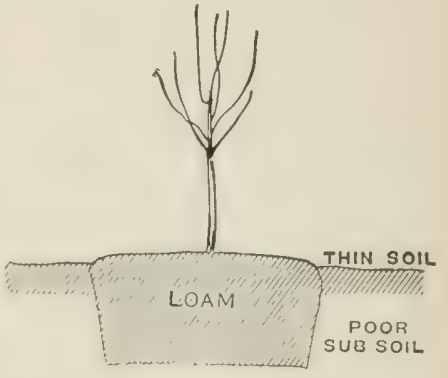

Fig. 14. Providing good soil in which to plant where the land lacks fertility hungry plants on New Jersey sand. He can't water anyway, but he don't want to; he does keep the ground always so actively stirred or cultivated as to be dusty, and the dust is a good preventive of evaporation from the soil. Hard ground drips water upward into the air; weeds and grass pour it upward. Therefore, cultivate, rather than water, under ordinary conditions.

26. To Make a Lawn. The charm of green grass about the home is admitted, and grass surely grows easily. To have it under that form of control which makes the result a good lawn, large or small, requires a little care. To begin with, there must be good soil, and of uniform depth, if the result is to be even and satisfactory. To have small portions of very good or very poor soil makes unsightly spots. If the home lawn is uneven, and if it has in it more grass than weeds, the sod should be lifted and the ground put in proper order. This is not

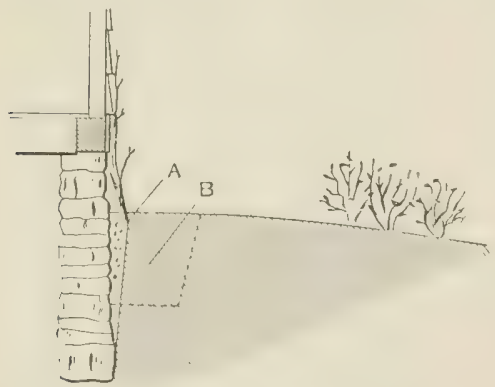

Fig. 15. Preparing for vine against the house. A, sterile soil; B, pocket of good loam very difficult; cut the sod in strips about fifteen inches wide and four or five feet long by striking through with a sharp spade, held vertically, using a line to keep straight. Then, with some one to help, cut under the grass at one end of the strip, to form a sod about three inches thick, or less, thus including most of the roots, and turn up the loosened end, rolling it with the grass inside, as you would roll up a thick rug. Figure 17 shows the idea, and also how to regrade a poor slope or an uneven surface.

With the sod removed, prepare the 
subsoil by thorough digging, to an even depth, working in a dressing of wellrotted manure if obtainable, or if not, some one of the many commercial lawn fertilizers. Whatever else you do, be sure thoroughly to mix the whole upper part of the ground to an even depth of fully twelve inches. If there are bad spots, remove the earth entirely from such, and substitute soil as good as the average. Dig, spade, rake, pulverize-make it even all through, and then roll it smooth, before relaying the sods.

In relaying the rolls of sod, join the edges smoothly-an old table-knife is a good tool to use. Fill in all crevices with good soil; pound the sods down with the flat of your spade-you cannot have them too solid. When all is smooth and even, water it thoroughly, soaking to the roots, and then sprinkle or sow pure lawn-grass seed, especially in any crevices you have filled. The kind of seed will vary with the locality and circumstances - blue grass is almost universally useful, but the seedsman will give you another grass-seed for shady spots.

27. To Sow a Lawn. Exactly the same preparation should be made as that described in Section 26, when it is proposed to make a new lawn. Dig, fertilize, pulverize, rake smooth, sow evenly and care-

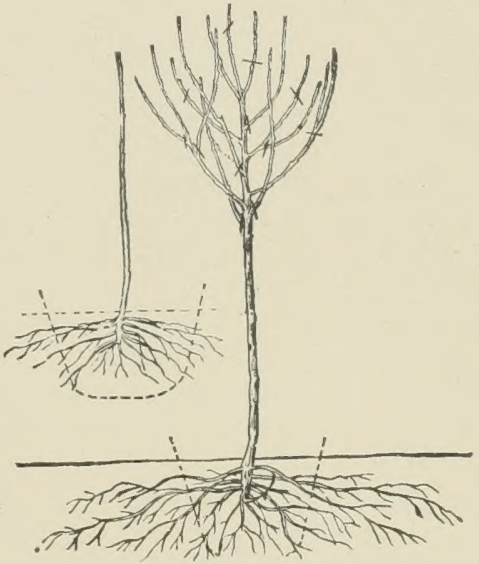

Fig. 16. Three-year-old tree in the nursery; dotted lines show how roots are cut in digging. Upper figure a one-year-old tree; nearly all the roots are saved. fully; sow plentifully; roll as soon as the new grass has had one cutting; fix up bare spots with more seed. A good lawn can be well started in three or four months under favorable circumstances. April and May, and September, are the best months in the latitude of New York. The idea is to sow while active growth is proceeding, and not in the heat of summer, or just before winter's advent.

28. Finally, Plant Something! Do it as well as you can, upon these or better hints; but plant anyway, even if you cannot do it all as you would wish. With some effort, some success is certain. Make the effort for a part of Beautiful America, and may your success be out of all proportion to the endeavor!

J. H. McF.

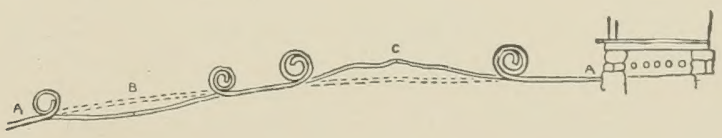

Fig. 17. Method of rolling up old sod and regrading a poor slope

$$
\text { [ } 15]
$$





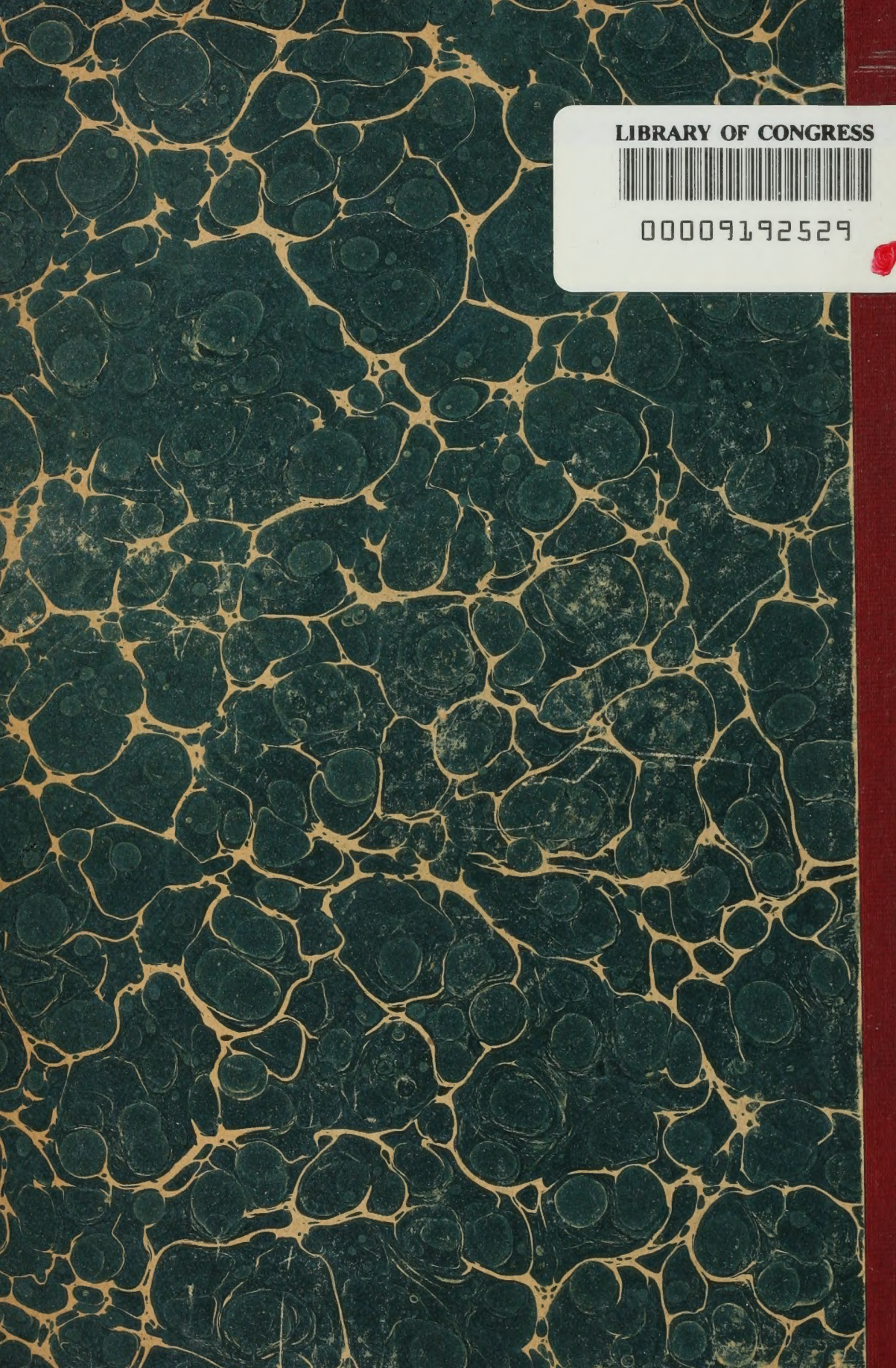

